\title{
TAFSIR AL-MISBAH \\ MUHAMMAD QURAISH SHIHAB
}

Oleh: Ali Geno Berutu

\section{A. Pendahuluan}

Al-Qur' an yang secara harfiah berarti “bacaan sempurna”merupakan suatu nama pilihan Allah yang sungguh tepat. Tidak ada bacaan melebihi al-Qur'an dalam perhatian yang diperolehnya, bukan saja sejarahnya secara umum, tetapi ayat-ayatnya, mulai dari dari masa, musim, dan saat turunnya, sampai sebab-sebab beserta waktu-waktu turunnya. H.A.R. Gibb seorang orientalis pernah menulis bahwa: "Tidak ada seorang pun dalam seribu lima ratus tahun ini telah memainkan "alat" bernada nyaring yang sangat mampu, berani dan luasnya getaran jiwa yang diakibatkan, seperti yang dibaca Muhammad (al-Qur'an)". Keindahan bahasanya demikian terpadu dalam al-Qur'an, ketelitian maupun keseimbangannya dengan kedalaman makna, kekayaan dan kebenarannya, serta kemudahan pemahaman dan kehebatan kesan yang ditimbulkannya. ${ }^{1}$

Al-Qur'an dapat berperan dan berfungsi dengan baik sebgai tuntunan dan pedoman serta petunjuk hidup untuk umat manusia, terutama di zaman kontemporer seperti saat ini. Oleh karena itu tidaklah cukup jika al-Qur'an hanya dianggap sebgai sebuah bacaan belaka dalam kehidupan sehari-hari tanpa dibarengi dengan pengertian dari maksud ayat tersebut. Mengunkap dan memahami alQur'an merupakan suatu upaya untuk mengurai isi serta makna yang terkandung didalamnya. Disisi yang lain sejarah mencatat bahwa al-Qur'an yang sudah lebih dari 1400 tahun lalu diturunkan untuk merespon kondisi, situasi sosial, politik, budaya dan relegiusitas masyarakat Arab tentu kondisi tersebut sangat jauh beda dengan kehidupan dan kondisi pada zaman global dan kontemporer saat ini. Maka dari itu penting untuk melakukan reinterpretasi terhadap al-Qur'an dengan melihat dan mempertimbangkan kondisi di mana dan kapan al-Qur'an itu turun. ${ }^{2}$

Pernyataan yang sama dilontarkan oleh Amin Abdullah bahwa perkembangan situasi sosial budaya, politik, ilmu pegetahuan dan revolusi informasi juga turut memberi andil dalam usaha memaknai teks-teks keagaamn. ${ }^{3}$ Shahrur berpendapat bahwa al-Qur'an pada zaman global sekarang ini perlu ditafsirkan sesuai dengan tuntutan zaman kontemporer yang dihadapi oleh umat

\footnotetext{
${ }^{1}$ M. Quraish Shihab, Wawasan al-Qur'an: Tafsir Maudu'i Atas Pelbagai Persoalan Umat, (Bandung: Mizan, 1996), 1-5.

${ }^{2}$ Atik Wartini, "Corak Penafsiran M. Quraish Shihab Dalam Tafsir Al-Misbah", Hunafa: Jurnal Studia Islamika, Vol. 11, No. 1, Juni 2014, 110.

${ }^{3}$ M. Amin Abdullah, "Kajian Ilmu Kalam di IAIN Menyongsong Perguliran Paradigma Keilmuan Keislaman Pada Era Melenium Ketiga”, al-Jami'ah: Journal of Islamic Studies, No. 65, 2000, 93.
} 
Islam dan umat manusia. Pemeliharaan dilakukan dengan pengkajian yang menyentuh realitas dan mencoba menyapa realitas lebih sensitif dan memfungsikannya dalam memahami realitas-realitas yang ada dengan interpretasi yang baru sesuai dengan keadaaan setempat. ${ }^{4}$

Salah satu yang menarik dari penafsiran kontemporer adalah tafsir alMisbah karya M. Quraish Shihab. Quraish Shihab melihat bahwa masyarakat muslim Indonesia sangat mencintai dan mengagumi al-Qur'an, hanya saja sebagian dari mereka itu hanya kagum pada bacaan dan lantunan dengan menggunakan suara merdu. Kenyataan ini seolah-olah mengindikasikan bahwa al-Qur'an hanya sekedar untuk dibaca saja. ${ }^{5}$ Sebenarnya bacaan dan lantunan al-Qur'an harus disertai dengan pemahaman dan penghayatan dengan menggunakan akal dan hati untuk mengungkapkan pesan-pesan yang terkandung di dalamnya. al-Qur'an telah memberikan banyak motivasi agar manusia merenungi kandungan-kandungannya melalui dorongan untuk memberdayakan akal pikirannya. Tradisi tilāwah, qirā' $a h$ dan tadabbur al-Qur'an merupakan upaya memahami dan mengamalkan al-Qur'an.

Beberapa tujuan M. Quraish Shihab menulis Tafsir al-Misbah adalah: pertama, memberikan langkah yang mudah bagi umat Islam dalam memahami isi dan kandungan ayat-ayat Alquran dengan jalan menjelaskan secara rinci tentang pesan-pesan yang dibawa oleh al-Qur'an, serta menjelaskan tema-tema yang berkaitan dengan perkembangan kehidupan Manusia. Karena menurut M. Quraish Shihab walaupun banyak orang berminat memahami pesan-pesan yang terdapat dalam al-Qur'an, namun ada kendala baik dari segi keterbatasan waktu, keilmuan, dan kelangkaan refrerensi sebagai bahan acuan. ${ }^{6}$

Kedua, ada kekeliruan umat Islam dalam memaknai fungsi al-Qur'an. Misalnya, tradisi membaca Q.S. Yāsin berkali-kali, tetapi tidak memahami apa yang mereka baca berkali-kalai terebut. Indikasi tersebut juga terlihat dengan banyaknya buku-buku tentang fadhilah-fadhilah surat-surat dalam al-Qur'an. Dari kenyatan tersebut perlu untuk memberikan bacaan baru yang menjelaskan tematema atau pesan-pesan al-Qur'an pada ayat-ayat yang mereka baca. ${ }^{7}$ Ketiga, kekeliruan itu tidak hanya merambah pada level masyarakat awam terhadap ilmu agama tetapi juga pada masyarakat terpelajar yang berkecimpung dalam dunia studi al-Qur'an, apalagi jika mereka membandingkan dengan karya ilmiah, banyak diantara mereka yang tidak mengetahui bahwa sistematika penulisan al-Qur'an

\footnotetext{
${ }^{4}$ M. Quraish Shihab, Membumikan al-Qu'an: Fungsi dan Peran Wahyu dalam Kehidupan Masyarakat (Bandung: al-Mizan, 2003), 88.

${ }^{5}$ M. Quraish Shihab, Tafsir Al-Misbah: Pesan, Kesan dan Keserasian al-Qur'an, Vol. I, (Jakarta: Lentera Hati, 2002), 4.

${ }^{6}$ Quraish Shihab, Tafsir al-Misbah... Vol. I, vii.

${ }^{7}$ Quraish Shihab, Tafsir al-Misbah...., x. 
mempunyai aspek pendidikan yang sangat menyentuh. ${ }^{8}$ Dan Keempat, adanya dorongan dari umat Islam Indonesia yang mengugah hati dan membulatkan tekad M. Quraish Shihab untuk menulis karya tafsir. ${ }^{9}$

\section{B. Biografi Singkat M. Qurais Shihab}

Muhammad Quraish Shihab merupakan salah seorang ulama dan cendikiawan muslim Indonesia dalam bidang tafsir al-Qur'an lahir pada tanggal 16 Februari 1944 di Rappang, Sulawesi Selatan. ${ }^{10}$ Beliau merupakan putra dari salah seorang wirausahawan dan juga seorang guru besar dalam bidang tafsir yang memiliki reputasi baik dalam dunia pendidikan di Sulawesi Selatan yaitu Prof. KH. Abdurrahman Shihab (1905-1986). Kontribusinya terbukti dalam usahanya membina perguruan tinggi di Ujung Pandang, yaitu Universitas Muslim Indonesia (UMI) dan IAIN Alauddin Ujung Pandang. Dalam kesibukannya sebagai seorang guru besar Abdurrahman Shihab masih sering menyisihkan waktunya untuk keluarganya, saat-saat seperti ini dimanfaatkan untuk memberikan petuah-petuah keagamaan yang kebanyakan berupa ayat-ayat al-Qur'an kepada putra-putrinya. ${ }^{11}$ Dari petuah-petuah keagamaan yang berasal dari ayat-ayat al-Qur'an, hadis-hadis nabi, serta perkataan sahabat maupun pakar-pakar ilmu al-Qur'an yang diberikan oleh orang tuanya inilah M. Quraish Shihab mendapatkan motivasi awal dan benihbenih kecitaan terhadap bidang studi tafsir. ${ }^{12}$

Pendidikan formal yang ditempuh oleh M. Qurais Shihab, dimulai dari Sekolah Dasar di Ujung Pandang, kemudian dilanjutkan dengan Sekolah Menengah, sambil belajar agama di Pondok Pesantren Dār al-Hadith al-Fiqhiyyah di kota Malang, Jawa Timur (1956-1958). ${ }^{13}$ Pada tahun 1958, ketikaia berusia 14 tahun ia melanjutkan pendidikan ke Al-Azhar Kairo Mesir untuk mendalami studi keislaman, dan diterima di kelas II Tsanawiyah al-Azhar. Setelah selesai, M. Quraish Shihab berminat melanjutkan studinya di Universitas al-Azhar pada Jurusan Tafsir Hadis Fakultas Ushuluddin, tetapi ia tidak diterima karena belum memenuhi syarat yang telah ditetapkan karena itu ia bersedia untuk mengulang setahun guna mendapatkan kesempatan studi di Jurusan Tafsir Hadis walaupun

${ }^{8}$ Quraish Shihab, Tafsir al-Misbah...., x.

${ }^{9}$ Hal ini dapat dilihat dalam Tafsir al-Misbah 15: 645. Bahwa M. Quraish Shihab pernah menerima surat dari seorang yang tidak dikenal yang menulis "Kami menunggu karya ilmiah pak Quraish yang lebih serius".

${ }^{10}$ Saiful Amin Ghafur, Profil Para Mufassir al-Qur'an (Yogyakarta: Pustaka Insan Madani, 2008), 236.

${ }^{11}$ Alwi Shihab, Islam Inklusif: Menuju Terbuka dalam Beragama, (Bandung: Mizan,1999), v.

12 Badiatul Raziqin, dkk, 101 Jejak Tokoh Islam Indonesia, (Yogyakarta: eNusantara, 2009), 269.

${ }^{13}$ M. Quraish Shihab, Membumikan al-Qur'an,(Bandung: Mizan, 1994), 6. 
jurusan-jurusan lain terbuka lebar untuknya. Pada tahun 1967 ia dapat menyelesaikan kuliahnya dan mendapatkan gelar Lc. Karena "kehausannya" dalam ilmu al-Qur'an ia melanjutkan kembali pendidikannya dan berhasil meraih gelar MA pada tahun 1968 untuk spesalisasi di bidang tafsir al-Qur'an dengan tesis berjudul “al-I'jāz at-Tashri'i al-Qur'ān al-Karīm” dengan gelar M.A. ${ }^{14}$

Setelah meraih gelar MA. M. Quraish Shihab tidak lansung melanjutkan studinya ke program doktor, melainkan kembali ke kampung halamannya di Ujung Pandang. Dalam periode lebih kurang 11 tahun (1969-1980) ia terjun ke berbagai aktifitas, membantu ayahnya mengelola pendidikan di IAIN Alauddin, dengan memegang jabatan sebagai Wakil Ketua Rektor di bidang Akdemis dan Kemahasiswaan (1972-1980), koordinator bidang Perguruan Tinggi Swasta Wilayah VII Indonesia bagian timur.

Selain di luar kampus M. Quraish Shihab dipercaya sebagai Wakil Ketua Kepolisian Indonesia Bagian Timur dalam bidang penyuluhan mental. Selama di Ujung Pandang ia melakukan berbagai penelitian, di antaranya dengan tema:"Penerapan Kerukunan Hidup Beragama di Indonesia Timur" (1975) dan"Masalah Wakaf di Sulawesi Selatan" (1978). Pada tahun 1980 M. Quraish Shihab kembali ke Kairo, Mesir untuk melanjutkan pendidikannya, mengambil spesialisasi dalam studi tafsir al-Qur'an, dalam kurun waktu dua tahun (1982) ia berhasil meraih gelar doktor dengan disertasi yang berjudul "Nazm al-Durar li alBiqa'i Tahqiiq wa Dirāsah" (suatu kajian terhadap kitab Naẓm al-Durar karya alBiqa'i) dengan predikat Summa Cum Laude dengan penghargaan Mumtāz Ma'a Martabat al-Syaraf al-Üla. ${ }^{15}$

Pada tahun 1984 beliau pindah tugas dari IAIN Alaudin, Ujung Pandang ke Fakultas Ushuluddin IAIN Syarif Hidayatullah Jakarta. Di sini M. Quraish Shihab aktif mengajar dalam bidang tafsir dan ulum al-Qur'an di program S1, S2, dan S3. dan beliau juga mendapat jabatan sebagai Rektor IAIN Jakarta dalam dua periode yaitu pada tahun 1992-1996 dan 1997-1998, ia juga dipercaya menjadi Menteri Agama selama kurang lebih dua bulan di awal tahun 1998, pada kabinet terakhir Soeharto, kabinet Pembangunan IV. Pada tahun 1999, M. Quraish Shihab diangkat menjadi Duta Besar Republik Indonesia untuk negara Republik Arab Mesir yang berkedudukan di Kairo.

\section{Karya-karya M. Quraish Shihab}

Sebagai mufassir kontemporer dan penulis yang produktif, M. Quraish Shihab telah menghasilkan berbagai karya yang telah banyak diterbitkan dan dipublikasikan.21 Diantara karyakaryanya, khususnya yang berkenaan dengan

\footnotetext{
${ }^{14}$ Badiatul Raziqin, dkk, 101 Jejak Tokoh Islam Indonesia,... 269-270

${ }^{15}$ M. Quraish Shihab, Membumikan al-Qur'an,... 6.
} 
studi Alquran adalah: Tafsir Al-Manar: Keistimewan dan Kelemahannya (1984), Filsafat Hukum Islam (1987), Mahkota Tuntunan Illahi: Tafsir Surat Al- Fatihah (1988), Membumikan Alquran: Fungsi dan Peranan Wahyu dalam Kehidupan Maysarakat (1994), Studi Kritik Tafsir al-Manar (1994), Lentera Hati: Kisah dan Hikmah Kehidupan (1994), Wawasan Alquran: Tafsir Maudhu'i atas Berbagai Persoalan Umat (1996), Hidangan Ayat-Ayat Tahlil (1997), Tafsir Alquran AlKarim: Tafsir Surat-surat Pendek Berdasarkan Urutan Turunya Wahyu (1997), Mukjizat Alquran Ditinjau dari Berbagai Aspek Kebahasaan, Isyarat Ilmiah dan Pemberitaan Ghaib (1997), Sahur Bersama M. Quraish Shihab di RCTI (1997), Menyingkap Ta'bir Illahi: al-Asma' al-Husna dalam Prespektif Alquran (1998), Fatwa-Fatwa Seputar Alquran dan Hadist (1999), dan lain-lain. ${ }^{16}$

\section{Sistematika Penafsiran.}

Sebelum masuk ke Surat, terdapat pendahuluan yang menjelaskan tentang: Jumlah ayat, tempat diturunkannya surat tersebut, surat yang diturunkan sebelum surat tersebut, pengambilan nama surat, hubungan dengan surat yang lain, serta gambaran menyeluruh tentang isi surat dan asbabun nuzul.

Diantara kelebihan tafsir ini adalah: Setiap Surat dikelompokkan menurut kandungannya, diberikan penjelasan terhadap kalimat yang terdapat dalam ayat, pada beberapa kalimat/kata, diberikan rujukan bagi pembaca jika ingin mengetahui penjelasan lebih lanjut, menyebutkan sumber (yang mengeluarkan) pendapat, serta dalam penerjemahan/penjelasan ayat, diberikan kalimat-kalimat tambahan sebagai penegasan (penjelasan).

Dalam konteks memperkenalkan al-Qur'an, penulis berusaha menghidangkan bahasan setiap surah pada tema pokok surah. Jika kita mampu memperkenalkan tema-tema pokok itu, maka secara umum kita dapat memperkenalkan pesan utama setiap surah sehingga al-Qur'an bisa dikenal lebih dekat dan mudah. Penulisan terjemah dipisahkan dengan tafsirnya. Terjemah ditulis dengan huruf miring, sedangkan tafsirnya ditulis dengan huruf normal. Tafsir al-Mishbah wajah baru dilengkapi dengan navigasi rujukan silang, dan dikemas dengan bahasa yang mudah dipahami serta pengemasan yang lebih menarik.

Quraish Shihab memulai dengan menjelaskan tentang maksud-maksud firman Allah swt sesuai kemampuan manusia dalam menafsirkan sesuai dengan keberadaan seseorang pada lingkungan budaya dan kondisisosial dan perkambangan ilmu dalam menangkap pesan-pesan al-Quran. Keagungan firman Allah dapat menampung segala kemampuan, tingkat, kecederungan, dan kondisi

${ }^{16}$ Atik Wartini, "Corak Penafsiran M. Quraish Shihab Dalam Tafsir Al-Misbah", Hunafa: Jurnal Studia Islamika, Vol. 11, No. 1, Juni 2014, 117. 
yang berbeda-beda itu. Quraish Shihab juga memasukkan tentang kaum Orientalis mengkiritik tajam sistematika urutan ayat dan surah-surah al-Quran, sambil melemparkan kesalahan kepada para penulis wahyu. Kaum orientalis berpendapat bahwa ada bagian-bagian al-Quran yang ditulis pada masa awal karir Nabi Muhammad saw.

Contoh bukti yang dikemukakannya antara lain adalah: QS. Al-Ghasyiyah. Di sana gambaran mengenai hari kiamat dan nasib orang-orang durhaka, kemudian dilanjutkan dengan gambaran orang-orang yang taat. Kemudian beliau mengambil tokoh-tokoh para ulama tafsir, tokoh-tokohnya seperti: Fakhruddin ar-Razi (606 H/1210 M). Abu Ishaq as-Ṣāthỉbỉ (w.790 H/1388 M), Ibrahim Ibn Umar al-Biqa'I (809-885 H/1406-1480 M), Badruddin Muhammad ibn Abdullah Az-Zarkași (w.794 H) dan lain-lain yang menekuni ilmu Munasabat al-Quran/keserasian hubungan bagian-bagian al-Quran. Tafsir al-Misbah terdiri dari 15 volume:

1. Al-Fātihah dan Al-Baqarah

2. Ali-'Imrān dan An-Nisā'

3. Al-Mā'idah

4. Al-An'ām

5. Al-A'rāf, Al-Anfāl dan At-Taubah

6. Yūnus, Hūd, Yūsuf dan Ar-Ra'd

7. Ibrāhīm, Al-Hijr, An-Naḥl dan Al-Isrā'

8. Al-Kahf, Maryam, Țāhā dan Al-Anbiyāa'

9. Al-Hajj, Al-Mu'minūn, An-Nūr dan Al-Furqān

10. Asy-Syu'ara, An-Naml, Al-Qasas dan Al-'Ankabūt

11. Ar-Rūm, Luqmān, As-Sajdah, Al-Aḩzāb, Saba', Fātị dan Yāsīn

12. As-Sāaffāt, Șād, Az-Zumar, Gāfir, Fușșilat, Asy-Syūrā dan Az-Zukhruf

13. Ad-Dukhān, Al-Jāsiyah, Al-Ahquāf, Muhammad, Al-Fatḥ, Al-Hujurāt, Qāf, Aż̇̇̇āriyāt, At-Tūr, An-Najm, Al-Qamar, Ar-Raḥmān dan Al-Wāqi'ah

14. Al-Ḥadid, Al-Mujādilah, Al-Ḥasyr, Al-Mumtahanah, Ass-Ṣaff, Al-Jumu'ah, Al-Munāfiqūn, At-Tagābun, Aț-Ṭalāq, At-Taḥrim, Al-Mulk, Al-Qalam, Al-Hāqqah, Al-Ma'ārij, Nuh, Al-Jinn, Al-Muzammil, Al-Muddašsir, AlQiyāmah, Al-Insān dan Al-Mursalāt

15. Juz ‘Amma

\section{E. Corak Tafsir Al-Misbah}

Tafsir al-Misbah cenderung bercorak sastra budaya dan kemasyarakatan (adabi al-ijtima 'i) yaitu corak tafsir yang berusaha memahami nash-nash al-Qur'an dengan cara mengemukakan ungkapan-ungkapan al-Qur'an secara teliti. Kemudian menjelaskan makna-makna yang dimaksud al-Qur'an tersebut dengan bahasa yang indah dan menarik, dan seorang mufassir berusaha menghubungkan nash-nash al- 
Qur'an yang dikaji dengan kenyataan sosial dengan sistem budaya yang ada. corak penafsiran ini ditekankan bukan hanya ke dalam tafsir lughawi, tafsir fiqh, tafsir ilmi dan tafsir isy'ari akan tetapi arah penafsirannya ditekankan pada kebutuhan masyarakat dan sosial masyarakat yang kemudian disebut corak tafsir Adabi alIjtimā' 1 . $^{17}$

Corak tafsir al-Misbah merupakan salah satu yang menarik pembaca dan menumbuhkan kecintaan kepada al-Qur'an serta memotivasi untuk menggali makna-makna dan rahasia-rahasia al-Qur'an. ${ }^{18}$ Menurut Muhammad Husein alDzahabi, corak penafsiran ini terlepas dari kekurangan berusaha mengemukakan segi keindahan bahasa dan kemu'jizatan al-Qur'an, menjelaskan makna-makna dan sasaran-sasaran yang dituju oleh al-Qur'an, mengungkapkan hukum-hukum alam yang agung dan tatanan kemasyarakatan yang di kandung, membantu memecahkan segala problem yang dihadapi umat Islam khususnya dan umat manusia pada umumnya, melalui petunjuk dan ajaran al-Qur'an untuk mendapatkan keselamatan di dunia dan akhirat serta berusaha mempertemukan antara al-Qur'an dengan teoriteori ilmiah yang benar. Di dalam al-Qur'an juga berusaha menjelaskan kepada umat manusia bahwa al- Qur'an adalah kitab suci yang kekal, yang mampu bertahan sepanjang perkembangan zaman dan kebudayaan manusia sampai akhir masa, yang berusaha melenyapkan kebohongan dan keraguan yang dilontarkan terhadap al-Qur'an dengan argumen yang kuat dan mampu menangkis segala kebatilan, sehingga jelas bagi mereka bahwa al-Qur'an itu benar. ${ }^{19}$

Ada tiga karakter yang harus dimiliki oleh sebuah karya tafsir bercorak sastra budaya dan kemasyarkatan. Pertama, menjelaskan petunjuk ayat al-Qur'an yang berkaitan langsung dengan kehidupan masyarakat dan menjelaskan bahwa alQur'an itu kitab suci yang kekal sepanjang zaman. Kedua, penjelasan-penjelasnnya lebih tertuju pada penanggulangan penyakit dan masalah-masalah yang sedang mengemuka dalam masyarakat, dan ketiga, disajikan dalam bahasa yang mudah dipahami dan indah didengar.

Tafsir al-Misbah karya M. Quraish Shihab memenuhi ketiga persyaratan tersebut. Kaitannya dengan karakter yang pertama, tafsir ini selalu menghadirkan penjelasan akan petunjuk dengan menghubungkan kehidupan masyarakat dan menjelaskan bahwa al-Qur'an itu kitab suci yang kekal sepanjang zaman. Kemudian karakter kedua, Quraish Shihab selalu mengakomodasi hal-hal yang dianggap sebagai problem di dalam masyarakat. Kemudian yang ketiga dalam

${ }^{17}$ Fajrul Munawwir, Pendekatan Kajian Tafsir, dalam M. Alfatih Suryadilaga (dkk), Metodologi Ilmu Tafsir, (Yogyakarta: Teras 2005), 138.

18 Said Agil Husein al-Munawar, Al-Qur'an Membangun Tradisi Kesalehan Hakiki, (Jakarta: Ciputat Press, 2002), 71.

19 Abdul Hayy Al-Farmawy, Metode Tafsir dan Cara Penerapannya, (Bandung: Pustaka Setia, 2002), 71-72. 
penyajiannya, tidak dapat diragukan, ia menggunakan bahasa yang membumi. M. Quraish Shihab menggunakan bahasa yang mudah dimengerti oleh kalangan umum khususnya masyarakat Indonesia. Sehingga jika dibandingkan dengan tulisantulisan cendekiawan muslim Indonesia lainnya.

Karya-karya M. Quraish Shihab pada umumnya dan Tafsir al-Misbah pada khususnya, tampil sebagai karya tulis yang khas. Memang, setiap penulis memiliki gaya masing-masing. Dalam memilih gaya bahasa yang digunakan, M. Quraish Shihab lebih mengedepankan kemudahan konsumen/pembaca yang tingkat intelektualitasnya relatif lebih beragam. Hal ini dapat dilihat dalam setiap bahasa yang sering digunakan M. Quraish Shihab dalam menulis karya-karyanya mudah dicerna dan dimengerti oleh semua lapisan khususnya di Indonesia.

Tafsir Al Mishbah secara garis besar memiliki corak kebahasaan yang cukup dominan. Hal ini bisa difahami karena memang dalam tafsir bil ra'yi pendekatan kebahasaan menjadi dasar penjelasannya dalam artian dengan cara menggunakan fenomena sosial yang menjadi latar belakang dan sebab turunya ayat, kemampuan dan pengetahuan kebahasaan, pengertian kealaman dan kemampuan Intelegensia. ${ }^{20}$

\section{F. Pendekatan Tafsir Al-Misbah}

M. Quraish Shihab banyak menekankan perlunya memahami wahyu Ilahi dengan pendekatan kontekstual dan tidak semata-mata terpaku pada makna tekstual agar pesan-pesan yang terkandung di dalamnya dapat difungsikan dalam kehidupan nyata. Pendekatan kontekstual adalah pendekatan yang berorientasi pada konteks penafsir al-Qur'an. Bentuk pendekatan ini menggunakan kontekstualitas dalam pendekatan tekstual yaitu latar belakang sosial historis di mana teks muncul dan diproduksi menjadi variable penting. Serta ditarik kedalam konteks penafsir di mana ia hidup dan berada, dengan pengalaman budaya, sejarah dan sosialnya sendiri. Oleh karena itu, sifat gerakannya adalah dari bawah ke atas, yaitu dari konteks menuju teks. ${ }^{21}$

Ada beberapa prinsip yang dipegangi oleh M. Quraish Shihab dalam karya tafsirnya, baik tahlili maupun maudhu'i, diantaranya adalah bahwa al-Qur'an merupakan satu kesatuan yang tak terpisahkan. Dalam menafsirkan beliau tidak luput dari pembahasan ilmu al-munasabah ayat yang tercermin dalam enam hal:

a. keserasian kata demi kata dalam satu surah;

b. keserasian kandungan ayat dengan penutup ayat;

c. keserasian hubungan ayat dengan ayat berikutnya;

${ }^{20}$ Abdul Mu'in Salim, Metodologi Ilmu Tafsir, (Yogyakarta: Teras, 2005), 99.

${ }^{21}$ Islah Gusmian, Khasanah Tafsir Indonesia dari Hermeneutika Hingga Ideologi, (Jakarta: Teraju, 2003), 249. 
d. keserasian uraian awal/mukadimah satu surah dengan penutupnya;

e. keserasian penutup surah dengan uraian awal/mukadimah surah sesudahnya;

f. Keserasian tema surah dengan nama surah.

\section{G. Metode Tafsir Al-Misbah}

Dalam menulis tafsir al-Miṣbāh, metode tulisan M. Quraish Shihab lebih bernuansa kepada tafsir taḥlili. Ia menjelaskan ayat-ayat al-Qur'an dari segi ketelitian redaksi kemudian menyusun kandungannya dengan redaksi indah yang menonjolkan petunjuk al-Qur'an bagi kehidupan manusia serta menghubungkan pengertian ayat-ayat al-Qur'an dengan hukum-hukum alam yang terjadi dalam masyarakat. Uraian yang ia paparkan sangat memperhatikan kosa kata atau ungkapan al-Qur'an dengan menyajikan pandangan pakar-pakar bahasa, kemudian memperhatikan bagaimana ungkapan itu dipakai dalam al-Qur'an. ${ }^{22}$

Dalam berbagai karyanya, M. Quraish Shihab lebih memilih metode maudlu'i dalam menyajikan pemikirannya dalam menafsirkan ayat-ayat al-Qur'an. Hal ini dilakukan karena metode maudlu'i (tematik) ini dapat mengungkapkan pendapat-pendapat al-Qur'an al-karim tentang berbagai masalah kehidupan, dan juga menjadi bukti bahwa ayat-ayat al-Qur'an sejalan dengan perkembangan iptek dan kemajuan peradaban masyarakat. Berbeda dengan hasil karyanya yang fenomenal tafsir al-Mishbah beliau menggunakan metode tahlili.

M. Quraish Shihab menafsirkan al-Qur'an secara kontekstual, maka corak penafsirannya dalam menafsirkan ayat-ayat al-Qur'an menggunakan Adabi ijtima'i (sosial kemasyarakatan). ${ }^{23} \mathrm{Hal}$ ini ia lakukan karena penafsiran al-Qur'an dari zaman ke zaman selalu mengalami perubahan sesuai dengan perkembanagan zaman dan kondisi yang ada. Disamping itu corak lugawi juga sangat mendominasi karena ketinggian ilmu bahasa arabnya. Corak sufi juga menghiasi tafsir al-Miṣbāh. Ketinggian bahasa arabnya dapat ditemukan kala mengungkap setiap kata (mufradat) mengenai ayat-ayat al-Qur'an.

Corak tafsir ini merupakan corak baru yang menarik pembaca dan menumbuhkan kecintaan kepada al-Qur'an serta memotivasi untuk menggali makna-makna dan rahasia-rahasia al-Qur'an. Menurut Muhammad Husain alDhahabi, bahwa corak penafsiran ini terlepas dari kekurangannya berusaha mengemukakan keindahan bahasa (balaghah) dan kemukjizatan al-Qur'an, menjelaskan makna-makna dan saran-saran yang dituju oleh al-Qur'an, mengungkapkan hukum-hukum alam yang agung dan tatanan kemasyarakatan

${ }^{22}$ Mahmud Yunus, Tafsir al-Qur'an al-Karim ( PT Hidakarya Agung, 2004), 4.

${ }^{23}$ Muhammad Ḥusain al-Dhahabi, al-Tafsìr wa al Mufassirūn, vol. 3 (Dār al-Kutub al-Hadithah), 213. 
yang dikandungnya membantu memecahkan segala problema yang dihadapi umat Islam khususnya dan umat manusia pada umumnya melalui petunjuk dan ajaran alQur'an untuk mendapatkan keselamatan dunia dan akhirat dan berusaha menemukan antara al-Qur'an dengan teori-teori ilmiah.

Misalnya ketika Quraish Shihab menafsirkan QS. Al-Fātiḥah (1) : 7, kata al-Ḍallin berasaldari kata dalla. Tidak kurang dari 190 kali kata tersebut terulang dalam al-Qur'an dalam berbagai bentuknya. Sedangkan kata dalla dalam bentuk alḌallūn (huruf lam di dhommah) ditemukan sebanyak 5 kali. Kata ini pada mulanya memiliki makna kehilangan jalan, bingung, dan tidak mengetaui arah. Maknamakna tersebut berkembang sehingga kata itu juga bisa mengandung arti binasa dan terkubur. Kata dalla dalam pengertian immaterial memiliki makna sesat dari jalan kebajikan atau lawan dari petunjuk.

Dari penggunaan al-Qur'an yang beraneka ragam tersebut dapat disimpulkan bahwa dalla dalam berbagai bentuknya mengandung arti tindakan atau ucapan yang tidak menyentuh kepada kebenaran. ${ }^{24}$ Tafsir al-Miṣbāh disajikan dalam bahasa yang ringan, enak dibaca dan mudah dipahami oleh berbagai kalangan, tidak heran jika karya ini di minati oleh berbagai elemen masyarakat, mulai dari kalangan intelektual muslim hingga seorang musisi.

\section{H. Kelebihan dan kekurangan Tafsir al-Misbah}

Di antara keistimewaan tafsir dengan corak kebahasaan adalah pada pemahaman yang seksama, karena tafsir dengan corak kebahasaan menekankan pentingnya penggunaan bahasa dalam memahami al-Qur'an, terjaminnya ketelitian redaksi ayat dalam penyampaian pesan-pesan yang dikandung al-Qur'an, kecilnya kemungkinan terjebaknya mufassir dalam subjektifitas yang terlalu jauh, karena pendekatan ini mengikat mufassir dalam bingkai pemahaman tekstual ayat-ayat alQur'an.

Sementara itu diantara kelemahan dari tafsir dengan corak kebahasaan, adalah: Kemungkinan terabaikannya makna-makna yang dikandung oleh AlQur'an, karena pembahasan dengan pendekatan kebahasaan menjadikan para mufassir terjebak pada diskusi yang panjang dari aspek bahasa. Di samping itu, seringkali latar belakang turunnya ayat atau asbab al-nuzul dan urutan turunnya ayat, termasuk ayat-ayat yang berstatus nasikh wa mansukh, hampir terabaikan sama sekali. Sehingga menimbulkan kesan seolah-olah Al-Qur'an tidak turun dalam ruang dan waktu tertentu.

Tafsir Al-Miṣbāh ini tentu saja tidak murni hasil penafsiran (ijtihad) Quraish Shihab saja. Sebagaimana pengakuannya sendiri, banyak sekali ia

${ }^{24}$ Quraish, al-Miṣbāh (Pesan, Kesan , Keserasian al-Qur'an), (Jakarta : Pelita Hati), Vol. 15, 11. 
mengutip dan menukil pendapat-pendapat para ulama, baik klasik maupun kontemporer. ${ }^{25}$ Yang paling dominan tentu saja kitab Tafsîr Nazm al-Durar karya ulama abad pertengahan Ibrahim ibn 'Umar al-Biqa'i (w. 885/1480). Ini wajar, karena tokoh ini merupakan objek penelitian Quraish ketika menyelesaikan program Doktornya di Universitas Al-Azhar. Muhammad Husein Thabathab'i, ulama Syi‘ah modern yang menulis kitab Tafsîr al-Mîzân lengkap 30 juz, juga banyak menjadi rujukan Quraish dalam tafsirnya ini. Dua tokoh ini kelihatan sangat banyak mendapat perhatian Quraish Shihab dalam Tafsir Al-Miṣaăh-nya. Selain al-Biqa'i dan Thabathaba'i, Quraish juga banyak mengutip pemikiranpemikiran Muhammad at-Thantawi, Mutawalli as-Sya'rawi, Sayyid Quthb dan Muhammad Thahir ibn Asyur. ${ }^{26}$

\section{Contoh Tafsir al-Misbah}

\section{Penciptaan manusia dalam surat al-An'am ayat 2}

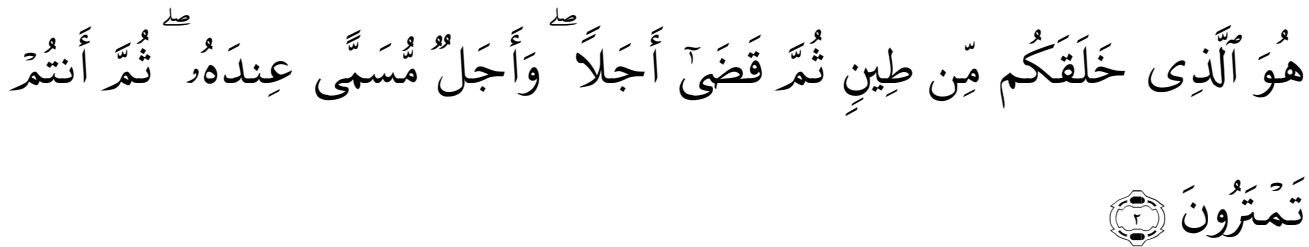

"Dialah yang menciptakan kamu dari tanah, sesudah itu ditentukan-Nya ajal dan ada lagi suatu ajal yang ditentukan di sisi-Nya, kemudian kamu masih terus-menerus ragu-ragu."

Dalam hal ini, penulis terkonsentrasi pada "sesudah itu ditentukan-Nya ajal dan ada lagi suatu ajal yang ditentukan di sisi-Nya". Menurut Quraish Shihab, pendapat yang terkuat tentang arti ajal adalah ajal kematian dan ajal kebangkitan karena biasanya al-Qur'an menggunakan kata "ajal" bagi manusia dalam arti kematian. Ajal yang pertama adalah kematian, yang paling tidak dapat diketahui oleh orang lain yang masih hidup setelah kematian seseorang. Sedangkan ajal yang kedua adalah ajal kebangkitan, yang tidak diketahui kecuali oleh Allah SWT.

Untuk memperkuat ini, kembali ditegaskan oleh Quraish bahwa pembentukan diri manusia, dengan segala potensi yang dianugrahkan Allah, menjadikan dia dapat hidup dengan normal, bisa jadi sampai seratus atau seratus

${ }^{25}$ Muhammad Iqbal, "Metode Penafsiran al-Qur'an M. Quraish Shihab”, Jurnal TSAQAFAH, Vol. 6, No. 2, Oktober 2010, 260.

${ }^{26}$ Quraish Shihab, Lentera Al-Qur'an: Kisah dan Hikmah Kehidupan (Bandung: Mizan, 2008), 10. 
dua puluh tahun; inilah yang tertulis dalam lauh al-mahwu wa al-itsbat. Tetapi semua bagian dari alam raya memiliki hubungan dan pengaruh dalam wujud atau kelangsungan hidup makhluk. Bisa jadi, faktor-faktor dan penghalang yang tidak diketahui jumlahnya itu saling memengaruhi dalam bentuk yang tidak kita ketahui sehingga tiba ajal sebelum berakhir waktu kehidupan normal yang mungkin bisa sampai pada batas 100 atau 120 tahun itu.

Quraish kembali menjelaskan, hal inilah yang dimaksud sementara ulama Ahlus Sunnah dinamai dengan qadha' muallaq dan qadha' mubram. Ada ketetapan Allah yang bergantung dengan berbagai syarat yang bisa jadi tidak terjadi karena berbagai faktor, antara lain karena doa, dan ada juga ketetapan-Nya yang pasti dan tidak dapat berubah sama sekali.

\section{Penciptaan Wanita}

Secara umum, diktum al-Qur'an menyebutkan bahwa penciptaan manusia dapat dibedakan menjadi empat macam kategori, yaitu (1) manusia diciptakan dari tanah (kasus Adam); (2) diciptakan dari tulang rusuk Adam (kasus Hawa). (3); diciptakan melalui kehamilan tanpa ayah (kasus Isa); (4) diciptakan melalui proses reproduksi lewat hubungan biologis antara suami-istri (manusia pada umumnya.

Ketiga bentuk penciptaan yang disebutkan pada poin 1, 3 dan 4, tidak ada perbedaan pendapat yang serius, baik dikalangan ahli tafsir maupun para feminis. Namun, untuk yang disebutkan kedua, yakni penciptaan melalui tulang rusuk Adam, yang dalam kasus ini adalah Hawa, sampai sekarang masih diperdebatkan, khususnya bagi para praktisi gender atau kaum feminis dan juga orang-orang yang sensitif gender. Sebab, konsep yang menyatakan bahwa Hawa diciptakan dari tulang rusuk Adam ini tidak saja berimplikasi pada sebuah pemahaman yang bias gender, tetapi juga berimplikasi secara psikologis, sosial, budaya, ekonomis dan bahkan politik. Artinya, secara kualitas Adam (laki-laki) lebih unggul dibandingkan dengan Hawa (perempuan).

Beberapa ayat al-Qur'an yang menegaskan masalah ini tidak menyebutkan secara jelas dan terperinci tentang proses penciptaan Hawa. Diktum al-Qur'an hanya menyebutkan bahwa "daripadanya (nafs wahidah), Dia menciptakan istrinya" (wa khalaqa minha zaujaha). Untuk lebih memperjelas masalah ini akan saya kutipkan beberapa ayat al-Qur'an yang menegaskan masalah ini, sebagai berikut: 


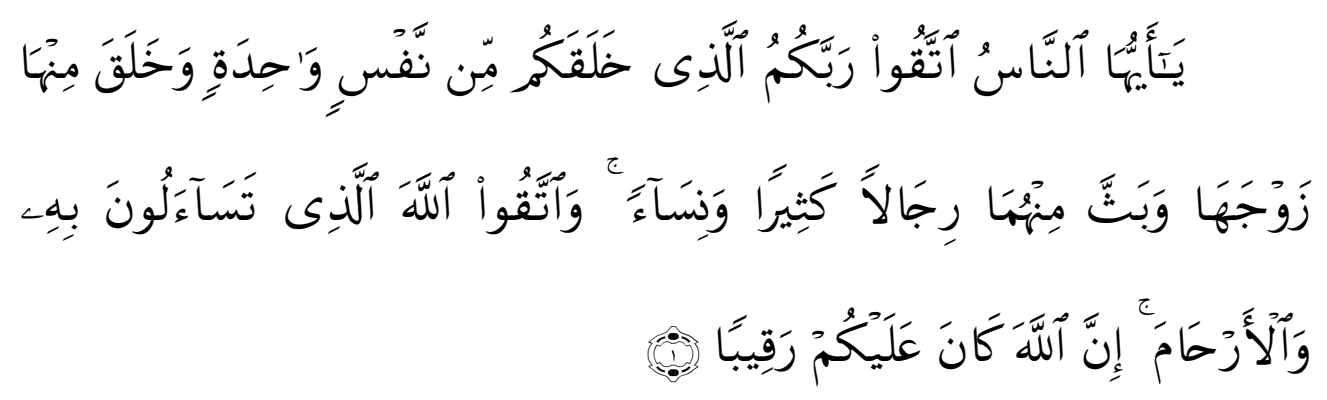

"Hai sekalian manusia, bertakwalah kepada Tuhan-mu yang telah menciptakan kamu dari diri yang satu, dan daripadanya Allah menciptakan isterinya; dan daripada keduanya Allah memperkembang biakkan laki-laki dan perempuan yang banyak. Dan bertakwalah kepada Allah yang dengan (mempergunakan) nama-Nya kamu saling meminta satu sama lain, dan (peliharalah) hubungan silaturrahim. Sesungguhnya Allah selalu menjaga dan mengawasi kamu" (QS. Al-Nisā' [4]: 1).

Dari ayat di atas, dapat dipahami bahwa Allah dalam hal ini tidak menyebutkan secara kronologis tentang proses penciptaan perempuan pertama itu. Diktum al-Qur'an, lagi-lagi hanya menyebutkan bahwa "daripadanya, Dia menciptakan pasangannya". Setidaknya, dalam konteks ini ada tiga hal penting yang memicu polemik di antara para mufassir ketika memahami beberapa ayat di atas, yaitu term nafs wahidah (diri yang satu); objek yang ditunjuk dengan kata minha (darinya); dan term zaujaha (pasangan).

Kontroversi disekitar penciptaan perempuan pertama ini setidaknya telah melahirkan dua pola pemahaman yang berbeda secara diametral. Pertama, bahwa Hawa diciptakan dari tulang rusuk Adam. Pengusung pendapat ini antara lain Imam al-Thabari. Menurutnya, yang dimaksud dengan term nafs wahidah yang terdapat dalam QS. Al-Nisa'/4: 1, adalah Nabi Adam, sementara term zaujaha diartikan sebagai Hawa. Pendapatnya itu didasarkan pada sebuah riwayat yang berasal dari Qatadah, al-Sadi dan Ibn Ishaq yang menyatakan bahwa Hawa diciptakan Allah dari tulang rusuk Adam sebelah kiri ketika dia sedang tidur. ${ }^{27}$

Pendapat al-Thabari di atas diamini mufassir lain seperti al-Alusi dan Ibn Katsir, al-Zamakhsyari, al-Qurtubi, dan juga al-Maraghi. Argumen mereka itu antara lain didasarkan pada sebuh hadis yang diriwayatkan oleh Imam al-Bukhari dan Muslim dari Abu Hurairah sebagai berikut:

${ }^{27}$ Muhammad Ibn Jarir al-Thabari, Jami' al-Bayan 'An Ta'wil Ayi al-Qur'an (Beirut: Dar al-Fikr, 1988), jilid. IV, 224-225. 
"Saling berpesanlah kalian untuk berbuat baik kepada perempuan, karena mereka diciptakan dari tulang rusuk. Sesungguhnya tulang rusuk yang paling bengkok adalah yang paling atasnya. Kalau engkau luruskan tulang yang bengkok itu, engkau akan mematahkannya, tetapi kalau engkau biarkan, dia akan tetap bengkok. Maka sekali olagi saling berpesanlah kalin untuk berbuat baik kepada perempuan" (HR. Bukhari dan Muslim). ${ }^{28}$

Kedua, bahwa Hawa tidak diciptakan dari tulang rusuk Adam, melainkan sebagai makhluk yang diciptakan dari jenis (jins) yang sama dengan Adam. Artinya, Hawa juga diciptakan dari tanah yang merupakan unsur utama dalam penciptaan Adam. Pendapat ini, antara lain dikemukakan oleh Abu Muslim al-Isfahani yang menyatakan bahwa maksud kalimat "wa khalaqa minha zaujaha" pada ayat tersebut adalah bahwa Allah menciptakan Hawa dari jenis yang sama dengan Adam. ${ }^{29}$ Pendapat senada juga dikemukakan oleh al-Razi. Dengan mengutip pendapat Isfahani, dia menyatakan bahwa dhamir (kata ganti) ha pada kata minha (dari padanya) pada ayat di atas, bukan merujuk pada Adam, melainkan "dari jenis" Adam, yaitu tanah. ${ }^{30}$

Pendapat senada juga dikemukakan oleh Muhammad Abduh dan muridnya Muhammad Rashid Ridha. Sedikitnya ada dua alasan mendasar yang dikemukakan Abduh untuk menolak pemahaman yang menyatakan bahwa maksud nafs wahidah dalam ayat tersebut berarti Adam. ${ }^{31}$ Pertama, ayat itu diawali dengan kalimat ya ayyuha al-nas (wahai sekalian manusia). Artinya, ayat ini ditujukan kepada seluruh umat manusia. Dengan demikian bersifat universal. Sementara itu, Adam tidak diakui secara universal sebagai manusia pertama. Oleh karenanya, pengertian min nafs wdhidah dalam ayat ini, seharusnya juga diakui secara universal.

Kedua, jika yang dimaksud dalam ayat tersebut adalah Adam (sebagai kata ma'rifah), mengapa lanjutan ayat itu menggunakan bentuk nakirah pada kata rijal dan nisa' pada kalimat wa bassa minhuma rijalan katsira wa nisa'an? Oleh karena itu, jika memang yang dimaksud dengan nafs wahidah adalah Adam, maka kedua kata itu seharusnya juga diungkapakan dengan bentuk ma'rifah.

Gagasan tentang asal-usul perempuan dari jenis yang sama dengan Adam ini juga diikuti oleh para feminis Indonesia. Dengan mengutip Riffat Hassan dan Fatima Mernissi, Zaitunah dalam bukunya, Tafsir Kebencian, mengklaim bahwa pendapat kedualah yang lebih rasional. Menurutnya, kata Adam dalam istilah

${ }^{28}$ Shahih Bukhari, Kitab al-Nikah pada bab al-Wushari bi al-Nisa', hadis nomor 4787, Lihat juga Ibn Katsir, I, 449.

${ }^{29}$ Abu Muslim al-Isfahani, Shahih Muslim, Jilid. II, 151.

${ }^{30}$ Fakhr al-Din al-Razi, Mafatih al-Ghaib (Beirut: Dar al-Fikr, 19950, Jilid. V, 168

${ }^{31}$ Muhammad Rasyid Ridha, Tafsir al-Qur'an al-Hakim (Tafsir al-Manar) (Beirut: dar al-Fikr, 1973), Jilid. IV, 223-230. 
bahasa Ibrani berarti 'tanah' - berasal dari kata Adamah - sebagian besar berfungsi sebagai istilah generik untuk manusia, bukan menyangkut jenis kelamin. Untuk memperkuat pendapatnya ini, dia lalu mengutip QS. Al-Isra'/17: 70 dan QS. AlTin/ 95: 4.2.

Nasaruddin Umar dalam Argumen Kesetaraan Jender juga berpandangan yang sama. Bahkan ia secara kritis memberikan analisis tentang term nafs dalam al-Qur'an dengan pendekatan linguistik. Menurutnya, term nafs yang terulang 295 kali dalam Al-Quran, dengan pelbagai bentuknya, tidak satu pun yang dengan tegas menunjuk kepada pengertian Adam. Kata nafs, dalam Al-Quran kadang berarti jiwa (QS Al-Ma'idah/5: 32), nafsu (QS. Al-Fajr/89: 27), nyawa/roh (QS. Al'Ankabut/29: 57), dan asal-usul binatang (QS. Syura/42: 11). ${ }^{32}$

Nasruddin Baidan dalam bukunya Tafsir bi Al-Ra'y juga berpandangan yang sama. Bahkan, dengan menggunakan analisis linguistik terhadap term nafs dalam al-Qur'an, dengan tegas dia menyimpulkan bahwa "wanita menurut AlQuran bukan diciptakan dari tulang rusuk Adam, melainkan dari unsur yang sama dengan Adam, yaitu tanah".33

Menanggapi persoalan ini, Quraish Shihab nampaknya memiliki pandangan yang berbeda dengan pandangan sebelumnya. Mungkin Quraish dalam hal ini tidak ingin berpolemik sebagaimana mufassir-mufassir lainnya. Quraish bisa jadi ingin memposisikan dirinya sebagai mufassir yang lebih bersikap moderat ketimbang harus menguatkan pendapat yang satu dan melemahkan pendapat yang lainnya. Dalam Tafsir al-Mishbah, ketika menjelaskan ayat pertama surah al-Nisa' ini, dia menulis sebagai berikut:

"Ayat Al-Hujurat memang berbicara tentang asal kejadian manusia yang sama dari seorang ayah dan ibu, yakni sperma ayah dan ovum/indung telur ibu. Tetapi, tekanannya pada persamaan hakikat kemanusiaan orang perorang, karena setiap orang walau berbeda-beda ayah dan ibunya, tetapi unsur dan proses kejadian mereka sama .... Adapun ayat al-Nisa' ini, maka walaupun ia menjelaskan kesatuan dan kesamaan orang-perorang dari segi hakikat kemanusiaan, tetapi konteksnya untuk menjelaskan banyak dan berkembangbiakannya mereka dari seorang ayah, yakni Adam, dan seorang Ibu, yakni Hawa. Ini dipahami dari pernyataan: Allah memperkembangbiakkan laki-laki yang banyak dan perempuan. Ini tentunya baru sesuai jika kata nafs wdhidah dipahami dalam arti ayah manusia seluruhnya (Adam AS)

\footnotetext{
${ }^{32}$ Nasaruddin Umar, Argumen Kesetaraan Jender (Jakarta: Paramadina, 1999), 241

${ }^{33}$ Nashruddin Baidah, Tafsir bi al-Ra'y: Upaya Penggalian Konsep Wanita dalam al-Qur'an (Yogjakarta: Pustaka Pelajar, 1999), 8-10.
} 
dan pasangannya (Hawa) lahir darinya laki-laki dan perempuan yang banyak. $^{34}$

Dari kutipan di atas, jelas bahwa Quraish Shihab memiliki pandangannya sendiri tentang asal-usul kejadian perempuan. Quraish memaknai kata nafs wahidah dalam pengertian "ayah manusia seluruhnya", yakni Adam dan pasangannya, Hawa. Sebab, dari situlah dimulainya perkembangbiakkan manusia, baik laki-laki dan perempuan. Pemaknaannya itu dia dasarkan pada kesesuaian makna dalam konteks wacana yang dibicarakan di dalam ayat tersebut. Bahkan, ia memandang paham soal asal-usul kejadian perempuan dari tulang rusuk Adam ini bukan sebagai sebab yang sering melahirkan bias gender. Ketika mengutip kritik Rasyid Ridla atas ide keterciptaan Hawa dari tulang rusuk Adam yang diklaim sebagai pengaruh dari Perjanjian Lama (Kejadian II: 21-22), lebih lanjut Quraish menulis:

"Perlu dicatat sekali lagi bahwa pasangan Adam itu diciptakan dari tulang rusuk Adam, maka itu bukan berarti bahwa kedudukan wanita-wanita selain Hawa demikian juga, atau lebih rendah dibanding dengan laki-laki. Ini karena semua pria dan wanita anak cucu Adam lahir dari gabungan antara pria dan wanita, sebagai mana bunyi surat Al-Hujurat di atas, dan sebagaimana penegasanNya, "Sebagian kamu dari sebagian yang lain" (QS. Ali 'Imran/3:195. Laki-laki lahir dari pasangan pria dan wanita, begitu juga wanita. Karena itu tidak ada perbedaan dari segi kemanusiaan antara keduanya. Kekuatan laki-laki dibutuhkan oleh wanita dan kelemahlembutan wanita didambakan oleh pria. Jarum harus lebih kuat dari kain, dan kain harus lebih lembut dari jarum. Kalau tidak, jarum tidak akan berfungsi, dan kain pun tidak akan terjahit. Dengan berpasangan, akan tercipta pakaian indah, serasi dan nyaman. ${ }^{35}$

Masih terkait dengan penciptaan perempuan pertama dari tulang rusuk Adam itu, Quraish menegaskan bahwa hadis itu harus dipahami secara majazi (kiasan). Sebab, jika tidak, lagi-lagi akan memunculkan pemahaman yang keliru, yang kemudian mengesankan bahwa derajat perempuan lebih rendah jika dibandingkan dengan laki-laki. Untuk meluruskan pemahaman terhadap hadis itu, Quraish menulis sebagai berikut:

${ }^{34}$ Muhammad Quraish Shihab, Tafsir al-Misbah: Pesan, Kesan dan Keserasian alQur'an, Vol. II. 314-315.

${ }^{35}$ Quraish Shihab, Tafsir al-Misbah, Vol. II ..., 316. 
"Tulang rusuk yang bengkok harus dipahami dalam pengertian majazi (kiasan), dalam arti bahwa hadis tersebut memperingatkan para lelaki agar menghadapi perempuan dengan bijaksana. Karena ada sifat, karakter, dan kecenderungan mereka yang tidak sama dengan lelaki, hal mana bila tidak disadari akan dapat mengantar kaum lelaki untuk bersikap tidak wajar. Mereka tidak akan mampu mengubah karakter dan sifat bawaan perempuan. Kalaupun mereka berusaha akibatnya akan fatal, sebagaimana fatalnya meluruskan tulang rusuk yang bengkok" ${ }^{36}$

Meskipun Quraish dalam pandangan-pandangannya sangat mengakui kesetaraan antara laki-laki dengan perempuan, karena dia bukan seorang feminis, maka dia juga tidak menolak model pemahaman yang pertama, yang menyatakan bahwa nafs wahidah dalam QS. al-Nisa'/4: 1, dimaknai sebagai Adam. Bahkan, Quraish dalam Tafsir al-Misbah, nampaknya lebih cenderung dengan pendapat yang pertama ini. Meskipun demikian, dia tetap berusaha untuk memaknainya secara proporsional tanpa harus merendahkan yang satu dan meninggikan yang lain. Ini dapat dilihat dari pendapat-pendapatnya sebagaimana di atas.

Hal yang demikian dapat dimaklumi, sebab Quraish bukanlah seorang feminis atau praktisi jender. Ini akan sangat berbeda sekali dengan para feminis yang sejak awal ingin mengusung ide-ide kesetaraan dan bahkan keadilan jender. Sehingga, pemahamannya tentang masalah ini akan berbeda jauh dengan, misalnya Nasaruddin Umar, Zaitunah, Nasruddin Baidan, dan yang sependapat dengannya.

Bahkan Islah, ketika membahas pandangan Quraish tentang hal penciptaan perempuan pertama ini menyimpulkan bahwa "Quraish lebih suka berlindung di balik pendapat ulama yang dirujuknya, dan tidak memperlihatkan pendapatnya sendiri secara tegas".

Menurut Islah, kecenderungan Quraish pada pendapat pertama yang dibarengi dengan pencitraan, setidaknya ada dua alasan pokok. ${ }^{37}$ Pertama, pasangan Adam yang diciptakan dari tulang rusuknya, bagi Quraish bukan berarti bahwa kedudukan wanita selain Hawa; lebih rendah ketimbang laki-laki. Semua pria dan wanita anak cucu Adam lahir dari gabungan antara pria dan wanita. Karena itu, tidak ada perbedaan dari segi kemanusiaan antara keduanya. Kedua, kekuatan laki-laki menurut Quraish dibutuhkan oleh wanita dan kelemahlembutan wanita didambakan oleh pria. Dengan metafor antara jarum dan kain, ia menjelaskan bahwa jarum harus lebih kuat dari kain, dan kain harus lebih lembut

${ }^{36}$ Muhammad Quraish Shihab, Membumikan al-Qur'an: Fungsi dan Peran Wahyu dalam Kehidupan Masyarakat (Bandung: Mizan, 2002), cet. 23, 271.

${ }^{37}$ Islah Gusmian, Khazanah tafsir Indonesia: Dari hermeneutika hingga Ideologi (Bandung: Teraju, 2003), 307-308. 
dari jarum. Kalau tidak, jarum tidak akan berfungsi, dan kain pun tidak akan terjahit.

Lebih lanjut Islam menyatakan bahwa Quraish dalam hal ini lebih menyembunyikan problem-problem pokok dari relasi laki-laki-perempuan. Pada alasan pertama, Quraish tidak melihat aspek psikologis dari konstruksi nalar tentang kisah keterciptaan Hawa dari tulang rusuk Adam. Memang, seperti logika yang dia pakai, kita akan mengakui bahwa generasi anak cucu Adam (baik laki-laki maupun perempuan) lahir dari hasil perkawinan dua jenis manusia: laki-laki dan perempuan. Namun, pokok persoalannya tidaklah berhenti pada kesadaran semacam ini. Sebab, kisah keterciptaan Hawa dari tulang rusuk Adam, secara psikologis telah mengonstruksi nalar dan bahkan menjadikan suatu pandangan dunia, bahwa perempuan adalah jenis manusia kelas dua, karena asal-usul keterciptaan Hawa tersebut.

Pada alasan kedua, Quraish telah memberikan pencitraan bias gender. Kelembutan perempuan yang dia gambarkan seperti kain, dan kekuatan laki-laki yang dia gambarkan seperti jarum, yang saling membutuhkan, jelas merupakan soal gender. Sebab, kekuatan dan kelembutan bukanlah dua hal yang bersifat kodrati, tetapi lebih sebagai suatu potensi dari hasil konstruksi pencitraan dalam wilayah sosial-budaya. Oleh karena itu, secara seksual, jarum tidaklah identik dengan jenis kelamin laki-laki, dan kain pun juga tidak identik dengan jenis kelamin perempuan.

\section{J. Penutup}

Quraish Shihab banyak menekankan perlunya memahami wahyu Ilahi secara kontekstual dan tidak semata-mata terpaku pada makna tekstual agar pesanpesan yang terkandung di dalamnya dapat difungsikan dalam kehidupan nyata. Ia juga banyak memotivasi mahasiswanya, khususnya di tingkat pasca sarjana, agar berani menafsirkan al-Qur'an, tetapi dengan tetap berpegang ketat pada kaidahkaidah tafsir yang sudah dipandang baku. Menurutnya, penafsiran terhadap alQur'an tidak akan pernah berakhir. Dari masa ke masa selalu saja muncul penafsiran baru sejalan dengan perkembangan ilmu dan tuntutan kemajuan. Meski begitu ia tetap mengingatkan perlunya sikap teliti dan ekstra hati-hati dalam menafsirkan al-Qur'an sehingga seseorang tidak mudah mengklaim suatu pendapat sebagai pendapat al-Qur'an. Bahkan, menurutnya adalah satu dosa besar bila seseorang mamaksakan pendapatnya atas nama al-Qur'an. 


\section{K. Daftar Pustaka}

Abdullah, M. Amin. "Kajian Ilmu Kalam di IAIN Menyongsong Perguliran Paradigma Keilmuan Keislaman Pada Era Melenium Ketiga”, al-Jami'ah: Journal of Islamic Studies, No. 65, 2000.

al-Dhahabi, Muhammad Husain. al-Tafsìr wa al Mufassirūn, vol. 3. Dār al-Kutub al-Hadithah.

Al-Farmawy, Abdul Hayy. Metode Tafsir dan Cara Penerapannya. Bandung: Pustaka Setia, 2002.

al-Munawar, Said Agil Husein. Al-Qur'an Membangun Tradisi Kesalehan Hakiki. Jakarta: Ciputat Press, 2002.

al-Razi, Fakhr al-Din. Mafatih al-Ghaib. Beirut: Dar al-Fikr, 19950, Jilid. V.

al-Thabari, Muhammad Ibn Jarir. Jami' al-Bayan 'An Ta'wil Ayi al-Qur'an. Beirut: Dar al-Fikr, 1988.

Baidah, Nashruddin. Tafsir bi al-Ra'y: Upaya Penggalian Konsep Wanita dalam alQur'an. Yogjakarta: Pustaka Pelajar, 1999.

Ghafur, Saiful Amin. Profil Para Mufassir al-Qur'an. Yogyakarta: Pustaka Insan Madani, 2008.

Gusmian, Islah. Khasanah Tafsir Indonesia dari Hermeneutika Hingga Ideologi. Jakarta: Teraju, 2003.

Iqbal, Muhammad. "Metode Penafsiran al-Qur'an M. Quraish Shihab", Jurnal TSAQAFAH, Vol. 6, No. 2, Oktober 2010.

Munawwir, Fajrul. Pendekatan Kajian Tafsir, dalam M. Alfatih Suryadilaga (dkk), Metodologi Ilmu Tafsir. Yogyakarta: Teras 2005.

Raziqin, Badiatul, dkk. 101 Jejak Tokoh Islam Indonesia. Yogyakarta: eNusantara, 2009.

Ridha, Muhammad Rasyid. Tafsir al-Qur'an al-Hakim (Tafsir al-Manar). Beirut: dar al-Fikr, 1973, Jilid. IV.

Salim, Abdul Mu'in. Metodologi Ilmu Tafsir. Yogyakarta: Teras, 2005.

Shahih Bukhari, Kitab al-Nikah pada bab al-Wushari bi al-Nisa', hadis nomor 4787.

Shihab, Alwi Islam Inklusif: Menuju Terbuka dalam Beragama. Bandung: Mizan,1999. 
Shihab, M. Quraish Membumikan al-Qu'an: Fungsi dan Peran Wahyu dalam Kehidupan Masyarakat. Bandung: al-Mizan, 2003.

Shihab, M. Quraish. Membumikan al-Qur'an. Bandung: Mizan, 1994.

Shihab, M. Quraish. Wawasan al-Qur'an: Tafsir Maudu'i Atas Pelbagai Persoalan Umat. Bandung: Mizan, 1996.

Shihab, Muhammad Quraish. Lentera Al-Qur'an: Kisah dan Hikmah Kehidupan. Bandung: Mizan, 2008.

Shihab, Muhammad Quraish. Membumikan al-Qur'an: Fungsi dan Peran Wahyu dalam Kehidupan Masyarakat. Bandung: Mizan, 2002.

Shihab, Muhammad Quraish. Tafsir al-Miṣbāh (Pesan, Kesan, Keserasian alQur'an). Jakarta : Pelita Hati, Vol. 15.

Shihab, Muhammad Quraish. Tafsir al-Misbah: Pesan, Kesan dan Keserasian alQur'an, Vol. II.

Umar, Nasaruddin. Argumen Kesetaraan Jender. Jakarta: Paramadina, 1999.

Wartini, Atik "Corak Penafsiran M. Quraish Shihab Dalam Tafsir Al-Misbah", Hunafa: Jurnal Studia Islamika, Vol. 11, No. 1, Juni 2014.

Yunus, Mahmud. Tafsir al-Qur'an al-Karim. PT Hidakarya Agung, 2004. 